\title{
Lagrangian analysis of microphysical and chemical processes in the Antarctic stratosphere: a case study
}

\author{
L. Di Liberto ${ }^{1}$, R. Lehmann ${ }^{2}$, I. Tritscher ${ }^{3,6}$, F. Fierli ${ }^{1}$, J. L. Mercer ${ }^{4}$, M. Snels ${ }^{1}$, G. Di Donfrancesco ${ }^{5}$, T. Deshler ${ }^{4}$, \\ B. P. Luo ${ }^{3}$, J-U. Grooß ${ }^{6}$, E. Arnone ${ }^{1}$, B. M. Dinelli ${ }^{1}$, and F. Cairo ${ }^{1}$ \\ ${ }^{1}$ Institute for Atmospheric Sciences and Climate, ISAC-CNR, Rome, Italy \\ ${ }^{2}$ Alfred Wegener Institute, Potsdam, Germany \\ ${ }^{3}$ Institute for Atmospheric and Climate Science, ETH Zurich, Zurich, Switzerland \\ ${ }^{4}$ Department of Atmospheric Science, University of Wyoming, Laramie, Wyoming, USA \\ ${ }^{5}$ Ente per le Nuove Tecnologie Energia e Ambiente, Santa Maria di Galeria, Rome, Italy \\ ${ }^{6}$ Institut für Energie und Klimaforschung - Stratosphäre (IEK-7), Forschungszentrum Jülich, Jülich, Germany \\ Correspondence to: F. Cairo (f.cairo@isac.cnr.it)
}

Received: 24 October 2014 - Published in Atmos. Chem. Phys. Discuss.: 22 December 2014

Revised: 29 April 2015 - Accepted: 29 May 2015 - Published: 16 June 2015

\begin{abstract}
We investigated chemical and microphysical processes in the late winter in the Antarctic lower stratosphere, after the first chlorine activation and initial ozone depletion. We focused on a time interval when both further chlorine activation and ozone loss, but also chlorine deactivation, occur.

We performed a comprehensive Lagrangian analysis to simulate the evolution of an air mass along a 10-day trajectory, coupling a detailed microphysical box model to a chemistry model. Model results have been compared with in situ and remote sensing measurements of particles and ozone at the start and end points of the trajectory, and satellite measurements of key chemical species and clouds along it.

Different model runs have been performed to understand the relative role of solid and liquid polar stratospheric cloud (PSC) particles for the heterogeneous chemistry, and for the denitrification caused by particle sedimentation. According to model results, under the conditions investigated, ozone depletion is not affected significantly by the presence of nitric acid trihydrate (NAT) particles, as the observed depletion rate can equally well be reproduced by heterogeneous chemistry on cold liquid aerosol, with a surface area density close to background values.

Under the conditions investigated, the impact of denitrification is important for the abundances of chlorine reservoirs after PSC evaporation, thus stressing the need to use appropriate microphysical models in the simulation of chlorine deactivation. We found that the effect of particle sedimentation
\end{abstract}

and denitrification on the amount of ozone depletion is rather small in the case investigated. In the first part of the analyzed period, when a PSC was present in the air mass, sedimentation led to a smaller available particle surface area and less chlorine activation, and thus less ozone depletion. After the PSC evaporation, in the last 3 days of the simulation, denitrification increases ozone loss by hampering chlorine deactivation.

\section{Introduction}

The depletion of ozone occurring in the polar stratosphere during winter and spring is linked to processes involving clouds in the polar stratosphere (Solomon et al., 1986). During winter, the polar stratosphere cools to temperatures below $195 \mathrm{~K}$, establishing a vortex circulation over the poles that separates the air inside from mid-latitudes, and allows for the formation of polar stratospheric clouds (PSC). Such clouds can be classified into three main particle types (Browell et al., 1990; Toon et al., 1990), Ia as solid trihydrates of nitric acid (NAT), Ib as supercooled ternary solutions of $\mathrm{H}_{2} \mathrm{O} / \mathrm{HNO}_{3} / \mathrm{H}_{2} \mathrm{SO}_{4}$ (STS) growing by $\mathrm{HNO}_{3}$ uptake by preexisting stratospheric sulfate aerosol (SSA), and type II as ice clouds, similar to tropospheric cirrus (Lowe et al., 2008). A new classification by Pitts et al. $(2007,2009,2011)$ emphasizes that PSC are often composed of mixtures of such 
particle types. PSC classifications have been critically reviewed in Achtert and Tesche (2014).

Extensive observations from ground-based as well as satellite instruments have provided climatologies of PSC occurrence in Antarctica (Adriani et al., 2004; Pitts et al., 2007; Di Liberto et al., 2014) and in the Arctic (Maturilli et al., 2005). STS-NAT mixtures are the predominant composition classes of PSC observed throughout the stratosphere from mid-June until mid-September in Antarctica, with NAT particles prevailing at altitudes above $15 \mathrm{~km}$ (Pitts et al., 2009). Over McMurdo, PSC of prevalently NAT type appear in early June to achieve maximum occurrence in July at $20-24 \mathrm{~km}$. The altitude of maximum occurrence has a downward trend from 24 to $14 \mathrm{~km}$ between July and September. PSC become increasingly rare to non-existent after the middle of October. Their presence is widespread over Antarctica, although regions of enhanced occurrence are present above and eastward of the Antarctic Peninsula.

Heterogeneous chemical reactions taking place on or within PSC particles convert relatively non-reactive chlorine reservoir species such as $\mathrm{ClONO}_{2}$ and $\mathrm{HCl}$ into active chlorine compounds such as $\mathrm{HOCl}, \mathrm{ClNO}_{2}$ and $\mathrm{Cl}_{2}$. Once the polar stratosphere has been primed by the action of heterogeneous chemistry on PSC particles, at the onset of spring, the sunlight photolyzes such compounds, releasing $\mathrm{Cl}$ that leads to catalytic ozone destruction.

Sedimentation of large PSC particles containing water and nitric acid causes dehydration and denitrification, depleting the stratosphere of water and nitric oxides that otherwise could reform chlorine reservoir species and reduce the lifetime of reactive chlorine. As the moderating effect of $\mathrm{NO}_{x}$ is missing, the considerable buildup of $\mathrm{ClO}$ drives the successive decrease in stratospheric ozone (Solomon, 1999).

The various kinds of PSC influence such processes differently: the conversion of chlorine from less to more reactive species takes place with a different efficiency, related to different PSC types (Biele et al., 2001; Carslaw and Peter, 1997; Tsias et al., 1999; Wegner et al., 2012); moreover, the sedimentation rate strongly depends on the average PSC particle size, which depends on its composition, phase and formation process.

In this paper, a case study of PSC evolution and its impact on ozone depletion and related processes in the late winter Antarctic stratosphere is presented. The study is based on in situ and remote sensing observations of trace gases and particles, and Lagrangian microphysical and chemical models. After a first observation of PSC optical characteristics, particle size distributions and ozone taken over McMurdo Station $\left(77^{\circ} 51^{\prime} \mathrm{S}, 166^{\circ} 40^{\prime} \mathrm{E}\right)$ by a set of balloon-borne in situ instruments and a ground-based lidar, the air mass has been tracked with a trajectory model until, after 10 days, air in a certain altitude range returned to McMurdo within a distance of less than $300 \mathrm{~km}$. Then, a second in situ balloon sampling and lidar measurement was accomplished. Satellite measurements of key chemical species and particles along the air- mass trajectories documented its microphysical and chemical evolution. This data set has been compared with simulations from chemical and microphysical box models reproducing the evolution of the cloud and evaluating its impact on the chemistry in the air mass. This well-documented case took place in early September, soon after the onset of ozone depletion from chlorine activation but before complete destruction of ozone, in a region close to the vortex edge. By modeling the microphysical and chemical processes along the trajectory and comparing simulations with observations, an assessment of the modeled denitrification, ozone chemistry, and the impact of PSC occurrence on ozone depletion can be made. Finally, an evaluation of the relative importance of the heterogeneous chemistry and denitrification will be made. The scope of this study is to provide a contribution to the most recent discussion of the relative role of PSC and liquid (background) aerosol in the ozone depletion (Drdla and Müller, 2012; Wegner et al., 2012; Wohltmann et al., 2013).

\section{Instruments and models}

\subsection{In situ instruments}

Balloon-borne instruments have been routinely launched from McMurdo Station since the 1980s (Mercer et al., 2007). Balloons are routinely equipped with instruments to measure ozone (Deshler et al., 2008), temperature, pressure and humidity, and occasionally with optical particle counters (OPC) (Hofmann and Deshler, 1991; Adriani et al., 1995; Deshler et al., 2003b).

Ozone measurements are performed with commercial electrochemical cell (ECC) ozonesondes, developed and described by Komhyr (1969). A Vaisala RS92 radio sonde performs pressure, temperature and humidity measurements using sensors designed to cover all atmospheric and weather conditions in every climate zone. The RS92 model provides temperature and pressure with an accuracy, respectively, of $0.25 \mathrm{~K}$ and $0.2 \mathrm{hPa}$ near $50 \mathrm{hPa}$ (Steinbrecht et al., 2008).

The OPC counts and sizes particles drawn into a sampling chamber. The single particle instrument uses white light scattering at $40^{\circ}$ in the forward direction to measure size using Mie theory. Deshler et al. (2003a) have described the measurement principles and their inherent uncertainties in significant detail, concluding that the uncertainties in size are in the range of $10 \%$ for most sizes, while concentration errors range from 8 to $80 \%$ for low concentrations. The impact of these uncertainties on integrals of the size distribution, such as surface area, are on the order of $\pm 40 \%$.

\subsection{Ground-based lidar}

McMurdo Station has been hosting a polarization diversity Rayleigh lidar since 1991 (Adriani et al., 2004), which was upgraded in 2004 (Di Liberto et al., 2014). The backscatter ratio, defined as the ratio of the total backscattered light 
to the one expected from an atmosphere free of aerosol, is retrieved by using the Klett algorithm, with an extinctionto-backscatter ratio (lidar ratio) calculated using the empirical model proposed by Gobbi et al. (1995). The ratio of the parallel to the cross polarization signals, the volume depolarization ratio $\delta$, is used to detect the presence of nonspherical (i.e., solid) aerosol. This quantity is calibrated with the method described by Snels et al. (2009). The aerosol depolarization ratio $\delta_{\mathrm{a}}$, retrieved from $\delta$ by eliminating the molecular contribution from the backscattering (Cairo et al., 1999), is a more direct characterization of the particle morphology, and is presented here. The uncertainty affecting these optical parameters has been estimated following the method reported in Russell et al. (1979) and is 0.1 (in absolute value) or $10 \%$ of the measured value (the larger of the two) for the aerosol backscatter ratio (BR-1) and $3 \%$ (in absolute value) or $10 \%$ of the measured value (the larger of the two) for the aerosol depolarization.

\subsection{Satellite instruments}

The Aura Microwave Limb Sounder (MLS) measures thermal emission continuously ( $24 \mathrm{~h}$ per day) using a limb viewing geometry that maximizes signal intensity and vertical resolution. Vertical profiles of mixing ratios of many different chemical species, temperature and pressure are derived (Waters et al., 2006). The MLS results for stratospheric ozone have been extensively validated and are in good agreement with other data sets from many different origins (Froidevaux et al., 2006). Ozone vertical profiles have a vertical resolution of approximately $3 \mathrm{~km}$ from 215 to $0.2 \mathrm{hPa}$ and about $4-6 \mathrm{~km}$ between 0.2 and $0.1 \mathrm{hPa}$. The ozone precision is $0.04 \mathrm{ppmv}$ in the range $215-68 \mathrm{hPa}, 0.1-0.4 \mathrm{ppmv}$ in the range 46-0.1 $\mathrm{hPa}$ and 1-0.06 ppmv between 0.05 and $0.02 \mathrm{hPa}$. The vertical resolution for the standard $\mathrm{HCl}$ product is $3 \mathrm{~km}$ in the stratosphere. The estimated single-profile precision reported for the Level 2 product varies from 0.2 to $0.6 \mathrm{ppbv}$ in the stratosphere. $\mathrm{HNO}_{3}$ data are reliable over the range $215-3.2 \mathrm{hPa}$, with a vertical resolution of 3-4 km in the upper troposphere and lower stratosphere. The precision is approx. 0.6-0.7 ppbv throughout the range from 215 to $3.2 \mathrm{hPa}$ (Santee et al., 2007). MLS ClO profiles have a vertical resolution of $3 \mathrm{~km}$ in the altitude range of interest for our study, and v2.2 data are reported with a precision of $0.1 \mathrm{ppbv}$ in the range $100-3 \mathrm{hPa} . \mathrm{H}_{2} \mathrm{O}$ profiles have a vertical resolution of about $2-3.5 \mathrm{~km}$ in the range $316-0.22 \mathrm{hPa}$, a precision of 6-8\% and an accuracy of 4-6\%. In the region and altitude of interest, MLS horizontal resolutions in along-track direction are reported to be on the order of $200-300 \mathrm{~km}$ for most targets (including $\mathrm{H}_{2} \mathrm{O}, 400-500 \mathrm{~km}$ for $\mathrm{ClO}$ ), cross-track resolution is approx. $3 \mathrm{~km}$, and the separation between adjacent retrieved profiles along the measurement track is $1.5^{\circ}$ great circle angle (approx. $165 \mathrm{~km}$ ). Further information on the MLS instrumentation and its products can be found at http://mls.jpl.nasa.gov/.
In our study, we have used MLS data in their version 2.2 generated by the GIOVANNI data analysis web application. We have considered MLS profiles when the MLS overpass was included in a box of $\pm 2^{\circ}$ lat and $\pm 15^{\circ}$ lon with a time difference less than $12 \mathrm{~h}$ with respect to the air-mass location along its trajectory. MLS data (delivered on pressure levels) were interpolated to find the mixing ratio at the isentropic levels (or altitudes) of our interest. This has been done by identifying the pressure value at the isentrope (or altitude) of interest from our radiosoundings, then linearly interpolating the MLS data in terms of logarithmic pressures.

MIPAS (Michelson Interferometer for Atmospheric limb Sounding) measured the upper tropospheric and stratospheric composition from a polar orbit on board the ESA ENVISAT satellite from 2002 to 2012 (Fisher et al., 2008). MIPAS was a limb-scanning Fourier transform interferometer that measured emission spectra in the thermal infrared, on a wide spectral range $\left(680\right.$ to $2410 \mathrm{~cm}^{-1}$ ). We adopted MIPAS data from the MIPAS2D database (Dinelli et al., 2010) (http://www.isac.cnr.it/ rss/mipas2d.htm) retrieved with the GMTR (Geo-fit Multi-Target Retrieval) analysis tool (Carlotti et al., 2006). The vertical resolution of MIPAS2D data is about $4 \mathrm{~km}$ for the altitude range of interest of this paper. The MIPAS along-track sampling step is about $410 \mathrm{~km}$. The width of the field of view at the tangent point in the crosstrack direction is about $30 \mathrm{~km}$. The smearing of information around the tangent point given by the width of the single scan horizontal averaging kernels is $200-300 \mathrm{~km}$, for most species (Raspollini et al., 2013). However, the MIPAS products used here are obtained by a 2-D (along-track) analysis code, and its horizontal resolution is limited by the $410 \mathrm{~km}$ sampling step adopted in the retrievals. Total systematic errors at the altitudes of interest for this study are 3-8\% for pressure, $0.7-1.5 \mathrm{~K}$ for temperature, $5-7 \%$ for ozone, and $5-20 \%$ for the other species. Random errors are $0.5-1.5 \%$ for pressure, $0.2-0.3 \mathrm{~K}$ for temperature, $2-5 \%$ for ozone, and $2-10 \%$ for the other species. We have considered MIPAS profiles when the overlap of the MIPAS overpass was included in a box of $\pm 2^{\circ}$ lat and $\pm 15^{\circ}$ lon with a time difference less than $12 \mathrm{~h}$ with respect to the air-mass location along its trajectory. Potential temperatures were self-consistently calculated from pressure and temperature, and the selected MIPAS2D profiles interpolated at the potential temperature level of the models.

The Cloud-Aerosol Lidar with Orthogonal Polarization (CALIOP) is a two-wavelength (532 and $1064 \mathrm{~nm}$ ) lidar, with two polarizations at $532 \mathrm{~nm}$, on board the CALIPSO (CloudAerosol Lidar and Infrared Pathfinder Satellite Observation) satellite that provides vertical profiles of aerosols and clouds, and has been extensively used for studies on PSC (Pitts et al., 2007, 2009, 2011). It has a vertical resolution between 30 and $60 \mathrm{~m}$ and a horizontal resolution of $333 \mathrm{~m}$ and $1 \mathrm{~km}$ for altitudes between 0.5 and $8.2 \mathrm{~km}$ and between 8.2 and $20.2 \mathrm{~km}$, respectively. The CALIPSO satellite is part of the A-Train track (Stephens et al., 2002). Since early 2008, CALIOP and 
MLS have taken measurements within about $30 \mathrm{~s}$ of one another. MLS profiles are separated by about $165 \mathrm{~km}$ along the orbit, while CALIPSO samples on a much finer horizontal resolution of approx. $1 \mathrm{~km}$ in the lower stratosphere (Lambert et al., 2012) and performs measurements on the same MLS geo-locations, only a few minutes later. In this work, we considered CALIOP profiles collected during night time and matching the $\pm 1.0^{\circ}$ latitude, $\pm 2.5^{\circ}$ longitude, $\pm 12 \mathrm{~h}$ time difference criteria, with respect to the traced air-mass location. More information on CALIOP can be found at http://www-calipso.larc.nasa.gov/.

Although satellite data lack the resolution and precision of in situ measurements, they have been used in the past for Lagrangian studies of the polar stratosphere (Santee et al., 2002; Sasano et al., 2000; Terao et al., 2002; Hoppel et al., 2005; Riviere, 2003), relying on averaging observations and trajectory matches over long periods. As we are interested in a single case study, this standard approach cannot be used, and our comparison between modeled result and satellite observation will suffer from the inaccuracy due to the spatial averaging inherent to the satellite observations. The extent of this inaccuracy cannot be known a priori, but should be kept in mind when discussing our results.

\subsection{Trajectory model}

During the field campaign, the air parcel trajectories were tracked by using the Goddard Space Flight Center (GSFC) isentropic trajectory model (http://acdb-ext.gsfc.nasa.gov/ Data_services/automailer/index.html). In the course of the data analysis, and for the purposes of this study, additional trajectory tools have been used for checking the results of the field campaign. For the purpose of microphysical modeling, the air parcel trajectories have been recalculated by the trajectory module of CLaMS (Chemical Lagrangian Model of the Stratosphere) using 6 hourly ERA-Interim (Dee et al., 2011) wind and temperature fields with a horizontal resolution of $1^{\circ} \times 1^{\circ}$. CLaMS is a modular chemistry transport model (CTM) system developed at Forschungszentrum Jülich, Germany (McKenna et al., 2002b, a; Konopka et al., 2004). Integration of trajectories has been accomplished with an integration time step of $15 \mathrm{~min}$. Vertical displacements of isentropic trajectories are derived from ERA-Interim total diabatic heating rates (Plöger et al., 2010). CLaMS produced forward trajectories from the time and location of the first PSC observation, starting on 10 September 2008 at 12:00 UTC. The vertical spacing between the trajectories is about $100 \mathrm{~m}$ in a vertical range between 350 and $450 \mathrm{~K}$. The GSFC and CLaMS trajectories document similar paths travelled by the air mass, although wind speed was slightly lower during the first days of the simulation in the ERA-Interim data set.

\subsection{Microphysical and optical model for PSC}

The Zurich Optical and Microphysical box Model (ZOMM) has been developed for PSC simulations to study the formation, growth and evaporation of PSC particles determined by changes in temperature and pressure. ZOMM includes the following PSC formation pathways: liquid background particles grow into STS droplets by uptake of $\mathrm{HNO}_{3}$ (Dye et al., 1992; Carslaw et al., 1995). Ice nucleation takes place either homogeneously at sufficiently low temperatures (Koop et al., 2000) or heterogeneously on the surfaces of foreign nuclei (Engel et al., 2013). NAT nucleation is implemented as heterogeneous nucleation on foreign nuclei (Hoyle et al., 2013) as well as on uncoated ice surfaces (Luo et al., 2003).

Small-scale temperature fluctuations, which are required to accurately reproduce ice number densities, are superimposed onto the synoptic-scale trajectories. The sedimentation of PSC particles is accounted for by using the column version of ZOMM as described in Engel et al. (2014). So far, ZOMM has always been initiated under typical background conditions for the winter polar stratosphere (Hoyle et al., 2013; Engel et al., 2013). The study by Engel et al. (2014) was the first study that used the microphysical model as a column model for PSC simulations. For the present study, we developed the model further and introduced the possibility of prescribing a particle size distribution. We extracted those data from the OPC measurements taken at the trajectory starting points and complemented the condensed amount of $\mathrm{H}_{2} \mathrm{O}$ and $\mathrm{HNO}_{3}$ with gas-phase values measured by MLS. The optical output, calculated using Mie and T-matrix scattering codes (Mishchenko et al., 2012), can directly be compared to CALIOP measurements. The calculated surface area of PSC along the trajectories serves as input for the chemistry model. Using a box model such as ZOMM for PSC studies allows a detailed microphysical calculation of cloud processes, which cannot be achieved with global models due to limited computing resources. Case studies without wind shear, as often observed in the polar vortex, offer the possibility of running ZOMM as a column version and, by doing this, of also simulating the vertical redistribution of particles.

\subsection{Chemistry model}

The temporal evolution of the mixing ratios of chemical species along trajectories was simulated by the Alfred Wegener Institute chemical box model. It contains 48 chemical species and 171 reactions, describing the stratospheric chemistry. It is based on a module for gas-phase chemistry described in Brasseur et al. (1997) and a module for heterogeneous chemistry reported in Carslaw et al. (1995). Reaction rate constants have been updated to the values given by Sander (2011). For these simulations, the initial mixing ratios of $\mathrm{ClO}, \mathrm{HCl}, \mathrm{HNO}_{3}, \mathrm{CO}, \mathrm{N}_{2} \mathrm{O}, \mathrm{H}_{2} \mathrm{O}$, and $\mathrm{O}_{3}$ were taken from the nearest MLS and ozonesonde measurements. The mixing ratios of $\mathrm{NO}_{x}\left(\mathrm{NO}, \mathrm{NO}_{2}\right)$ and $\mathrm{ClONO}_{2}$ were 


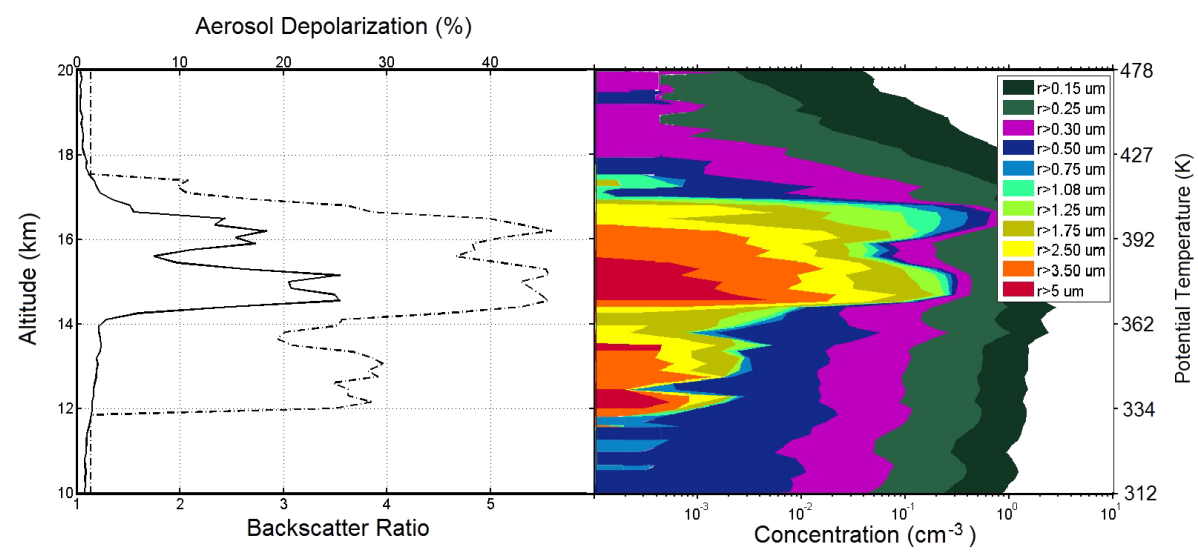

Figure 1. Left panel: altitude profiles of backscatter (solid line) and aerosol depolarization (dashed line) ratio measured by lidar. Right panel: altitude profiles of optical particle counter integrated size distributions; the colors indicate different lower diameter thresholds from 0.15 to $5 \mu \mathrm{m}$, as reported in the legend.

assumed to be close to 0 , in agreement with the MIPAS $\mathrm{ClONO}_{2}$ observations. Inspection of MLS maps for $\mathrm{H}_{2} \mathrm{O}$, $\mathrm{HNO}_{3}, \mathrm{ClO}, \mathrm{O}_{3}, \mathrm{HCl}$, and $\mathrm{N}_{2} \mathrm{O}$ available at the $56 \mathrm{hPa}$ level at http://mls.jpl.nasa.gov/plots/mls/mls_plot_locator.php for 10 September 2010 shows relatively low meridional gradients of the species of interest over McMurdo, thus giving confidence in the low spatial variability of the values used to initialize our model calculations. To start with balanced initial values, pre-runs of the chemical box model on a 1-day back-trajectory ending at the start point of the corresponding main trajectory were performed. The initial mixing ratios for these pre-runs were iteratively modified, until the MLS measurements were reproduced by the model at the end of the pre-run trajectory. Then, the mixing ratios of all species at the end of the pre-run were used as initial values for the run of the chemical box model on the main trajectory. As part of this procedure, a $\mathrm{ClO}_{x}\left(=\mathrm{ClO}+2 \cdot \mathrm{Cl}_{2} \mathrm{O}_{2}\right)$ mixing ratio consistent with the MLS ClO measurement was determined, which is essential for a correct simulation of the chemical ozone depletion.

\section{Observations and simulations}

\subsection{McMurdo observations}

A balloon carrying an OPC and an ozonesonde was launched from the Antarctic station of McMurdo on 10 September 2008, 10:55 UTC. Lidar measurements were simultaneously made during the $4 \mathrm{~h}$ duration of the balloon flight. A PSC was observed for $70 \mathrm{~min}$ in the initial part of the flight, during ascent, over a horizontal distance of $\sim 50 \mathrm{~km}$. The left panel of Fig. 1 depicts the lidar backscatter (solid line) and aerosol depolarization (dotted line) ratios vs. altitude, averaged over the OPC observation time, while the right panel shows the particle size distribution measurements obtained by the OPC. A layered PSC can be clearly discerned between

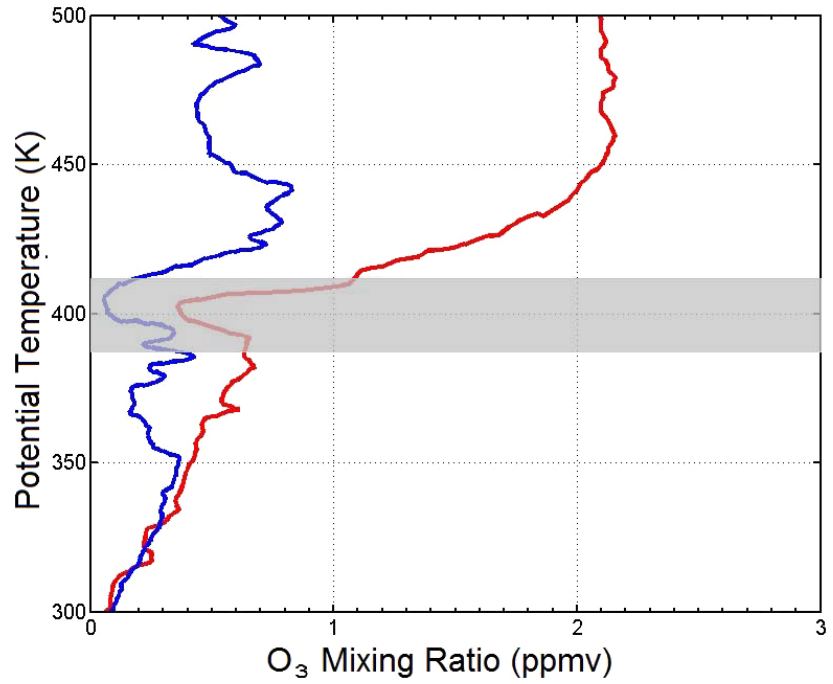

Figure 2. $\mathrm{O}_{3}$ measurements from the in situ ozonesonde (red line) on 10 September 2008, and on 20 September 2008 (blue line), vs. potential temperature. The grey area highlights the air layer that returned over the Ross Sea less than $300 \mathrm{~km}$ from McMurdo.

11.5 and $17.5 \mathrm{~km}(\sim 330-420 \mathrm{~K}$ potential temperature). The lowermost layer shows small backscatter ratio values, but significant depolarization around $30 \%$, typical of NAT PSC. The two layers between $14(\sim 360 \mathrm{~K})$ and $17 \mathrm{~km}$ show a higher backscatter ratio of about 3 and 2.5, depolarization around $40 \%$, again characteristic values for NAT PSC. The particle size distribution confirms this classification, particles above $1 \mu \mathrm{m}$, typical of NAT particles (Voigt et al., 2000) reaching concentrations of up to $10^{-1} \mathrm{~cm}^{-3}$. Temperatures (not shown) were above the ice freezing temperature $T_{\text {ice }}$ all along the profile.

Back-trajectory analysis showed that, in the 10 days preceding the observation, the air in which the PSC was detected 

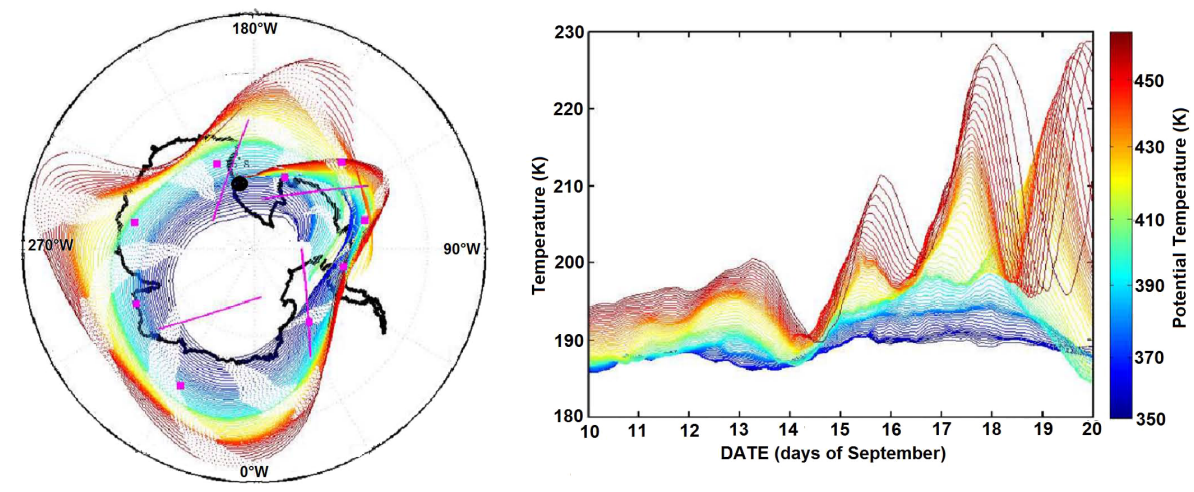

Figure 3. Left panel: air-mass trajectories originating from McMurdo (black dot) and run 10 days forward, color coded according to potential temperature. Solid colored lines indicate sunlit legs; dotted lines indicate legs in darkness. Purple lines specify intersections with the CALIOP footprint. Purple dots indicate where $\mathrm{MLS}$ data $\left(\mathrm{O}_{3}, \mathrm{HNO} 3\right.$ or $\left.\mathrm{HCl}\right)$ were available. Right panel: temperature values along the trajectories, again color coded in terms of potential temperature.

remained south of $60^{\circ} \mathrm{S}$, its temperature going below $195 \mathrm{~K}$ on 4 September, reaching $182 \mathrm{~K}$ the subsequent day and then hovering around $190 \mathrm{~K}$ for the days prior to our observation.

The red solid line in Fig. 2 shows the measured ozone profile in the $300-500 \mathrm{~K}$ potential temperature range, corresponding approximately to altitudes between 10 and $20 \mathrm{~km}$. The ozone values on 10 September fall within the climatological variability reported in Kröger et al. (2003) at the onset of the mid-September ozone depletion. During the campaign, we tracked the air mass sampled by the in situ instruments with the GSFC trajectory model, finding that after approximately 10 days, the air between 380 and $420 \mathrm{~K}$ potential temperature (where the PSC was observed) returned over the Ross Sea less than $300 \mathrm{~km}$ from McMurdo. A second balloon sounding was performed on 20 September, 07:30 UTC, to match the return of the air mass close to the $400 \mathrm{~K}$ level. During this second balloon sounding, and in the $24 \mathrm{~h}$ preceding it, lidar measurements (not shown) showed no sign of PSC. The ozone profile, in Fig. 2 with a blue solid line, showed reduced values between 360 and $420 \mathrm{~K}$ ( 14 and $17 \mathrm{~km}$ ), in the altitude region where the PSC was observed 10 days earlier. There, the ozone was reduced from 500-600 to $100-200$ ppbv on average. Very different ozone values between the two samplings are also discernible in the uppermost part of the sounding between 420 and $500 \mathrm{~K}$ (above 17 up to $20 \mathrm{~km}$ ). The grey area in Fig. 2 marks the altitude region where the air-mass reencounter was expected. There, the two profiles show a similar depression with minima at $405 \mathrm{~K}$. In that region, the ozone decrease between the two soundings is about $300 \mathrm{ppbv}$ below $405 \mathrm{~K}$, a little more above.

These ozone losses are comparable with what was observed in the past (Mercer et al., 2007; Kröger et al., 2003) in the same period of the year. The double overpass of the air mass over McMurdo in the layer between 380 and $420 \mathrm{~K}$ suggested a detailed Lagrangian study of the microphysics and chemistry that occurred in the air mass, between the two balloon observations.

In the left panel of Fig. 3, isentropic air mass trajectories, starting from McMurdo on 10 September 2008, 12:00 UTC, are shown (color coded according to potential temperature). Solid/dotted portions of the lines designate the sunlit/dark sectors of the trajectories. The right panel reports temperature histories along those trajectories (again color coded in terms of their potential temperature). The trajectories in the $375-425 \mathrm{~K}$ layer remained confined within the vortex and show a limited variability in PV (not shown). Air masses close to the $400 \mathrm{~K}$ level returned over McMurdo after approximately 9.5 days. In those air masses, the PSC was observed on 10 September and temperatures remained below $195 \mathrm{~K}$ for the initial 5 days of the trajectory. Then, the air masses experienced a warming in the second part of the trajectory.

To compare the results of our model simulations with observational data along the path of the air mass, coincidences between the air-mass trajectory and CALIOP and MLS observations were determined. In the leftmost panel of Fig. 3, purple dots indicate availability of MLS data, and purple lines crossing the trajectories specify intersections with the CALIOP footprint.

Figure 4 shows longitude vs. altitude curtains of backscatter ratio from CALIOP nighttime footprints crossing the airmass trajectory at various stages of its evolution. Red circles indicate the intersection of the curtain with the $400 \mathrm{~K}$ isoentropic trajectory. CALIOP data document the presence of a large PSC observed between 15 and $17.5 \mathrm{~km}$ on 14 September (daytime footprint, not shown), with values of the optical parameters that are the same order of magnitude of those observed above McMurdo 4 days earlier. On the next day, the top of a weak PSC is present in the region intersected by the air trajectory. Its shape resembles the previous day's observations. On the night of 16 September, the PSC is almost completely dissipated and vanishes in the following days. 

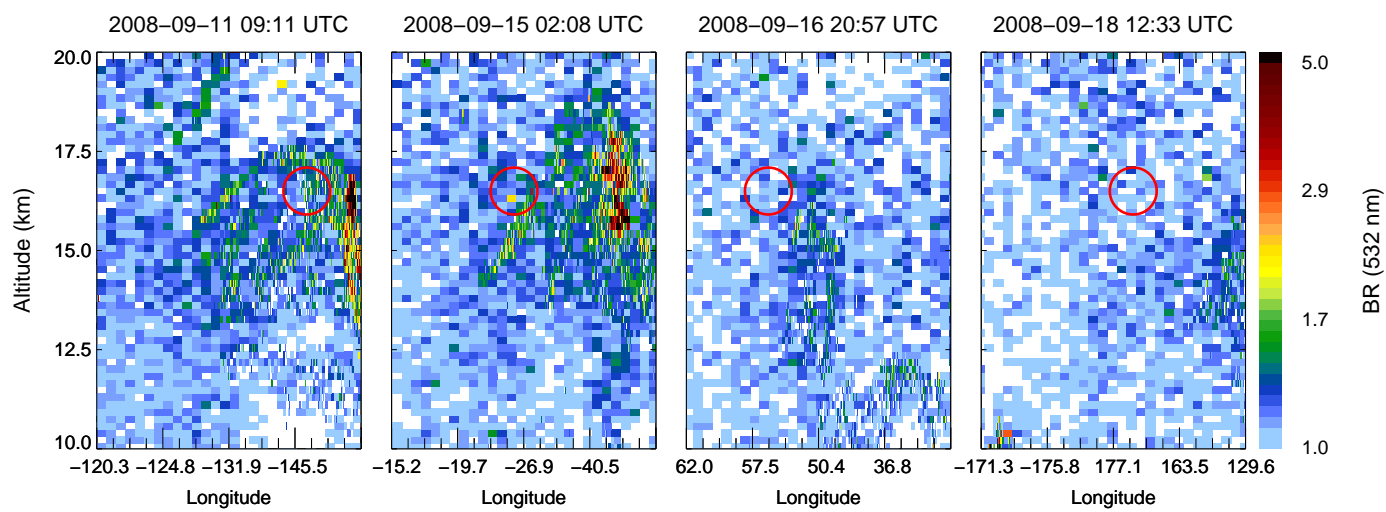

Figure 4. CALIOP backscatter ratio (color coded) vs. altitude and longitude. Red circles highlight the intersection with the $400 \mathrm{~K}$ isentropic trajectory.
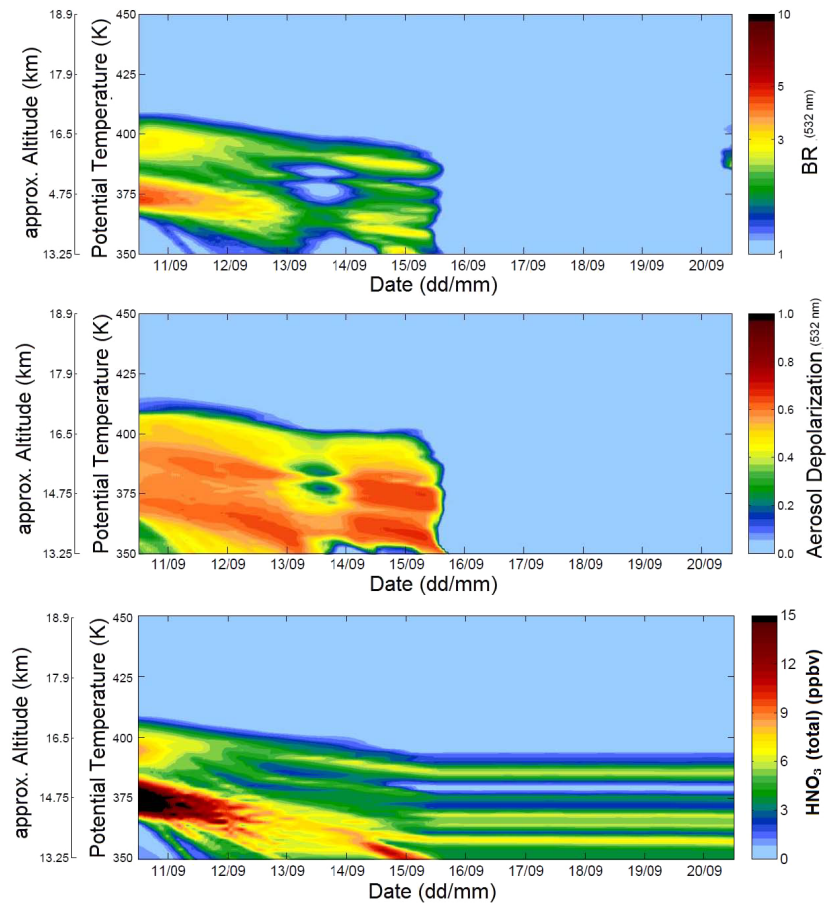

Figure 5. Profiles of backscatter ratio (upper panel), aerosol depolarization ratio (middle panel) and total $\mathrm{HNO}_{3}$ (lower panel) starting from the observations taken on 10 September 2008, and evolving according to the microphysical model.

The CALIOP depolarization (not shown) indicates that observations are consistent with a dominantly NAT PSC. The CALIOP observations document a large PSC in the area crossed by the trajectory of the air mass that was sampled 5 days earlier by the in situ aerosol measurements from McMurdo.

\subsection{Microphysical simulations}

The microphysical model was initialized with $\mathrm{MLS} \mathrm{H}_{2} \mathrm{O}$ and $\mathrm{HNO}_{3}$ profiles closest in time and space to the first McMurdo balloon sounding. Since those values are gas-phase values only, the amount of $\mathrm{HNO}_{3}$ taken up by existing STS droplets and NAT particles at the time of the PSC observation had to be computed. For those calculations, we made use of the size distribution measured by the balloon-borne OPC. The smallest size bins up to $0.75 \mu \mathrm{m}$ were considered to consist of STS droplets with a density of $1.44 \mathrm{~g} \mathrm{~cm}^{-3}$. Larger particles of the OPC size distribution were taken as NAT particles and the condensed $\mathrm{HNO}_{3}$ phase was computed by assuming spherical NAT particles with a density of $1.62 \mathrm{~g} \mathrm{~cm}^{-3}$. With these assumptions, estimates of $\mathrm{HNO}_{3}$ content in the particles larger than $\sim 0.3 \mu \mathrm{m}$ ranged from $20-30 \mathrm{ppbv}$ from $370-385 \mathrm{~K}(14.5-15.5 \mathrm{~km})$, to near $10 \mathrm{ppbv}$ from $385-405 \mathrm{~K}$ $(15.5-16.8 \mathrm{~km})$. While these values are higher than expected, they result from the OPC measurements of significant concentrations $\left(\sim 0.1 \mathrm{~cm}^{-3}\right)$ of particles in the $2-3 \mu \mathrm{m}$ range, so are not easily dismissed. A possible overestimation of the $\mathrm{HNO}_{3}$ content in the condensed phase from particle size measurements was reported in some recent airborne measurements from the RECONCILE campaign (von Hobe et al., 2013), and possible reasons for that are extensively discussed in Molleker et al. (2014). The microphysical run was initialized with an estimate of the initial value of total $\mathrm{HNO}_{3}$ of $6.9 \mathrm{ppbv}$, of which $5.2 \mathrm{ppbv}$ was in condensed phase, considered as a realistic upper limit for the amount of $\mathrm{HNO}_{3}$ in the particles. Results from this run will be presented here. The OPC size distribution was also used to prescribe existing NAT particles at the starting point of the trajectories. Temperature and pressure along the trajectories computed with the CLaMS trajectory module were used as input to predict the PSC evolution.

Figure 5 shows the modeled evolution of the PSC in terms of backscatter ratio (upper panel), aerosol depolarization (middle panel) and total $\mathrm{HNO}_{3}$ (lower panel) during the 

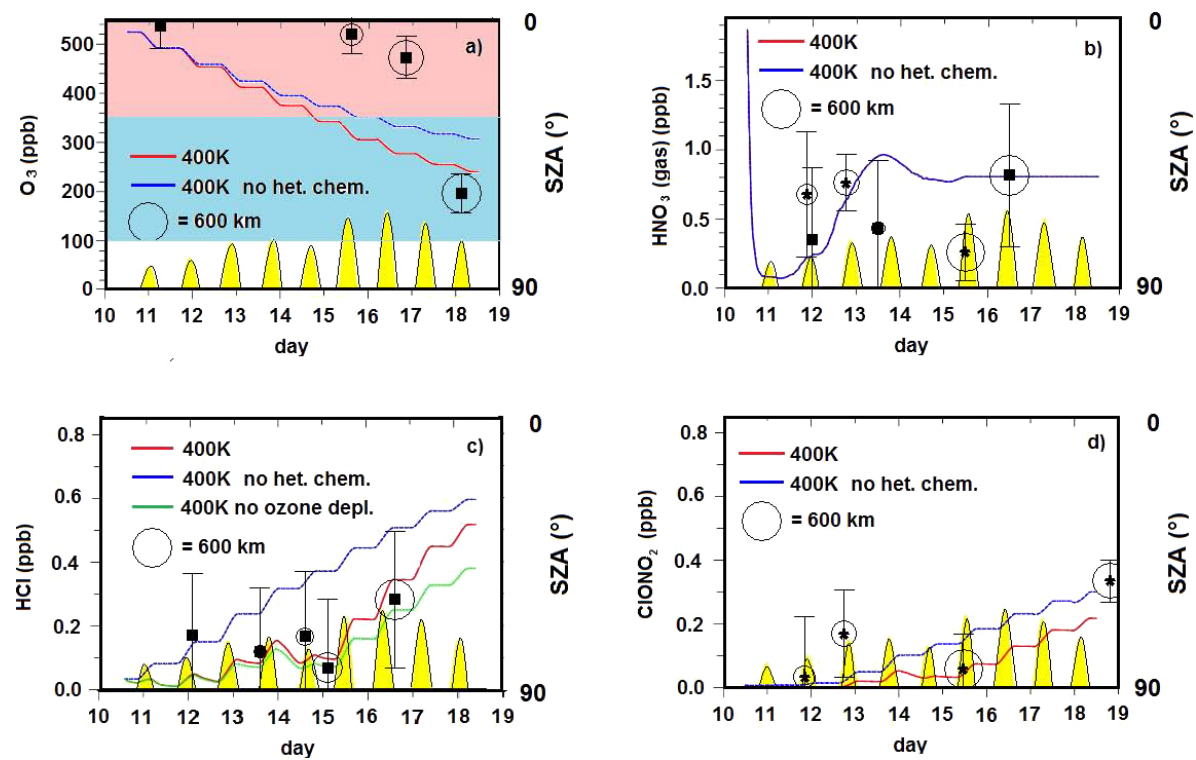

Figure 6. MLS (squares) and MIPAS (stars) observations and model results with (red line) and without (blue line) heterogeneous chemistry. (a) (Upper left panel) $\mathrm{O}_{3}$ : the colored areas highlight the range of variability of $\mathrm{O}_{3}$ values observed by the balloon-borne ozonesonde in the $400 \pm 10 \mathrm{~K}$ air layer that returned over the Ross Sea less than $300 \mathrm{~km}$ from McMurdo: red for the first flight, blue for the second flight; (b) (upper right) $\mathrm{HNO}_{3}$; (c) (lower left) $\mathrm{HCl}$; (d) (lower right) $\mathrm{ClONO}_{2}$. The radius of the circles surrounding the data points represents the match radius. Yellow areas indicate sunlit parts of the trajectory; the corresponding solar zenith angle (SZA) is reported on the right vertical axis.

10-20 September period. The persistence of the PSC for almost a week is evident. The cloud remains of NAT type for 6 days after the first McMurdo balloon sounding, and totally evaporates 3 days before the second McMurdo sounding, as a warming caused its disappearance before 16 September. This warming in the second part of the trajectory coincides with an increasing distance of the air mass from the vortex center. A vertical redistribution of the cloud is also evident, caused by the modeled particle sedimentation. The cloud vertical extent changes from $410-360 \mathrm{~K}(\sim 17-14 \mathrm{~km}$ in geometrical altitude) to $390-350 \mathrm{~K}(\sim 16.5-13.5 \mathrm{~km})$ in 6 days. A large vertical redistribution of the gas-phase $\mathrm{HNO}_{3}$ can be seen after the evaporation of the PSC. This occurrence has been confirmed by MLS $\mathrm{HNO}_{3}$ data on locations along the $400 \mathrm{~K}$ trajectory.

\subsection{Chemical simulations}

Chemistry model runs were performed along the CLaMS trajectories. Although the model has a microphysical module, it was forced to use prescribed values of $\mathrm{HNO}_{3}$ (total and gas phase), STS/SSA and NAT aerosol surfaces, as provided offline by the microphysical model output. This is because only the microphysical model could take into account particle sedimentation. The calculations were stopped at the trajectory point closest to McMurdo.

\subsubsection{Effects of heterogeneous chemistry}

Two model runs were performed, respectively, with and without the inclusion of heterogeneous chemistry. We hereafter present results of the simulations at the $400 \mathrm{~K}$ isentropic level, in the middle of the altitude region of the air-mass trajectory match. As shown in Fig. 2, a trough in the ozone profile at $400 \mathrm{~K}$ implies that ozone depletion has markedly occurred already before the time of the first sounding. This isentropic level is close to the upper limit of the PSC observed on 10 September, so it is where the consequences of particle sedimentation and $\mathrm{HNO}_{3}$ redistribution were likely to be more pronounced, as the microphysical simulation shows in Fig. 5, reporting profiles of backscatter ratio and aerosol depolarization. At $400 \mathrm{~K}$, the NAT particle surface area decreased steadily from an initial value of $4.5 \mu \mathrm{m}^{2} \mathrm{~cm}^{-3}$ to 0 in $100 \mathrm{~h}$, while STS/SSA particle surface area hovered around $1.5 \mu \mathrm{m}^{2} \mathrm{~cm}^{-3}$ throughout the simulation, a value not far from that expected for the background aerosol surface area density (Hitchman et al., 1994; Chayka et al., 2008).

Figure 6 reports the results of the chemistry simulations, with (red line) and without (blue line) heterogeneous chemistry taken into account. Yellow regions represent sunlit parts of the trajectory. Figure 6a reports $\mathrm{O}_{3}$ evolution. Removing heterogeneous reactions leads to less chlorine (re-)activation and, consequently, less ozone loss. However, the effect is not very strong, because most of the chlorine is already activated at the beginning of the trajectory, according to MLS data. 

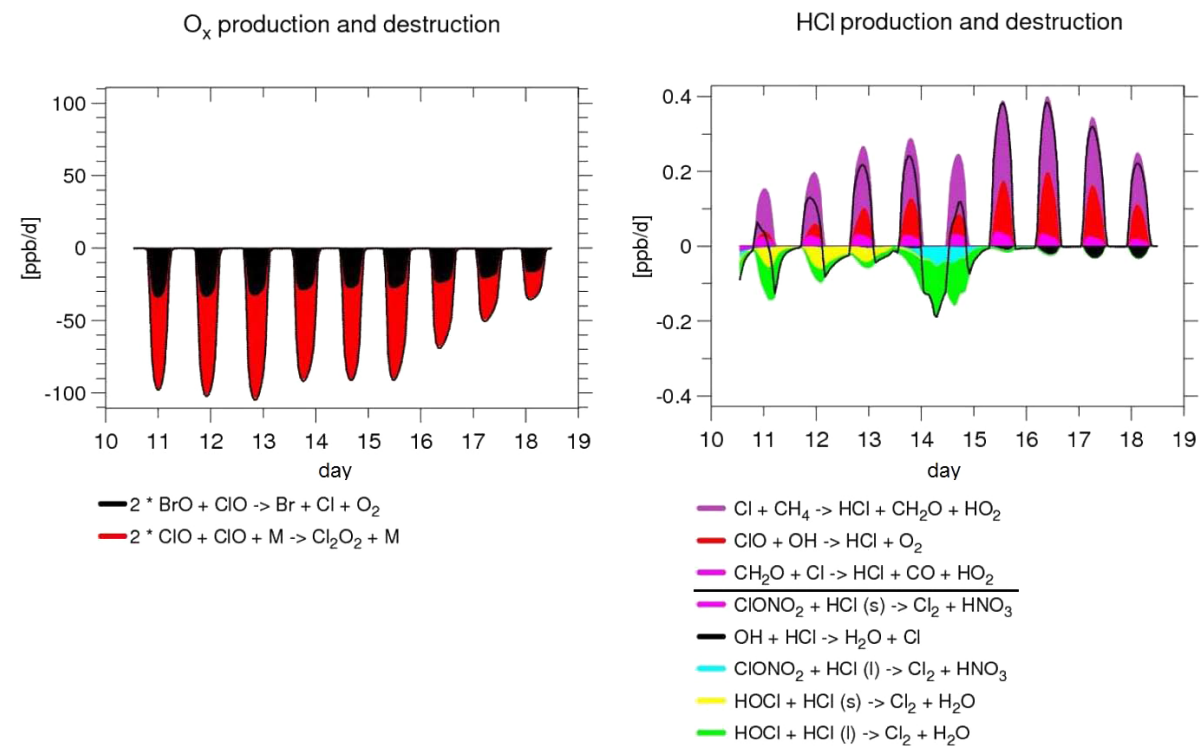

Figure 7. Left panel: $\mathrm{O}_{3}$ depletion rates due to $\mathrm{ClO}-\mathrm{BrO}$ (black) and $\mathrm{ClO}-\mathrm{ClO}$ (red) catalytic cycles. Right panel: $\mathrm{HCl}$ production and depletion rates due to the set of reactions listed at the bottom of the panel. Simulations have been carried out on the $400 \mathrm{~K}$ isentropic level.

Squares represent ozone measured by MLS along the trajectory. There, and in the following panels, the radius of the circles surrounding the data points represents the match radius, defined as the distance between the observation and the location of the air mass on its trajectory, at the time of the observation. The simulations capture the integrated ozone loss well, although intermediate comparisons are not good, as the large depletion is delayed in the observations until after 15 September. Such behavior should not be expected in the present case, where both $\mathrm{ClO}_{x}$ and sunlight are available for ozone depletion throughout the whole period. In the comparison with the measurements, however, it has to be taken into account that positions of the satellite measurements and corresponding trajectory points do not usually coincide. Moreover, limb soundings represent averages over large horizontal distances, and therefore might not have been able to fully account for processes going on in a relatively small portion of air.

$\mathrm{HNO}_{3}$ concentrations, both total and gas phase, were not calculated by the chemistry model, but were prescribed by the microphysical model. Figure $6 \mathrm{~b}$ reports on the evolution of the modeled $\mathrm{HNO}_{3}$ in the gas phase, driven initially by PSC particle condensation and successive evaporation after a vertical redistribution and removal due to particle sedimentation. Squares and stars represent, respectively, MLS and MIPAS data. In this case, the agreement between simulation and observation seems reasonable, although the measured uncertainties are large and the MIPAS and MLS scarcely agree with each other, with the MLS more consistent with the model. The microphysical model seems to reproduce well both the $\mathrm{HNO}_{3}$ sequestering in condensed phase until 14 September, and then some denitrification. Note again that sedimentation processes are very localized and their effects are observed by satellites only if the effects cover a large area.

Heterogeneous chemistry affects the evolution of $\mathrm{HCl}$ (Fig. 6c) and $\mathrm{ClONO}_{2}$ (Fig. 6d), respectively. As long as the PSC is present, both species are reduced by heterogeneous reactions. MLS $\mathrm{HCl}$ values are reported as squares and MIPAS ClONO 2 values are reported as stars.

The comparison with the observed values seems to suggest that the simulation with heterogeneous chemistry active is more effective in reproducing the $\mathrm{HCl}$ evolution over the studied period. However, as the speed of $\mathrm{Cl}$ deactivation is sensitively dependent on ozone mixing ratios (Douglass et al., 1995; Grooß et al., 1997, 2011), but the ozone comparison is not fully satisfactory, it is difficult to interpret this $\mathrm{HCl}$ and $\mathrm{ClONO}_{2}$ comparison. In order to estimate how sensitively $\mathrm{HCl}$ depends on the accuracy of ozone mixing ratio evolution in the present case, an additional sensitivity model run was then performed under the rather extreme assumption that there is no ozone depletion at all (i.e., by holding constant the ozone mixing ratio to its initial value throughout the simulation). Results of this sensitivity run are reported as a green solid line. The induced change in the $\mathrm{HCl}$ evolution is not too large, and $\mathrm{HCl}$ mixing ratios of the sensitivity run are still compatible with the MLS measurements between 12 and 17 September.

A closer look at the reactions affecting ozone and $\mathrm{HCl}$ is presented in Fig. 7, reporting the $\mathrm{O}_{3}$ depletion rates due to the $\mathrm{ClO}-\mathrm{BrO}$ and $\mathrm{ClO}-\mathrm{ClO}$ catalytic cycles (left panel) and the $\mathrm{HCl}$ production and destruction rates (right panel) due to a set of competing reactions listed at the bottom of the figure. Ozone is mainly destroyed by the $\mathrm{ClO}$ dimer 


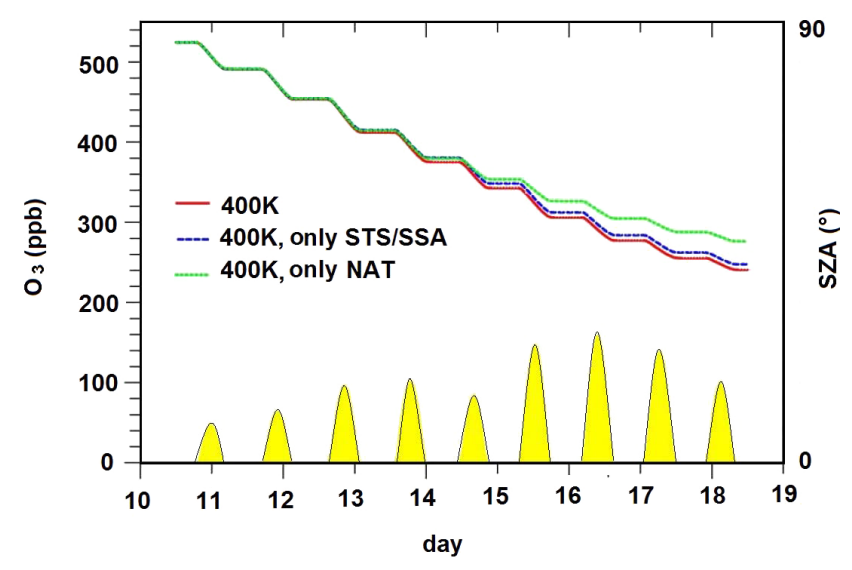

Figure 8. $\mathrm{O}_{3}$ evolution taking into account the full heterogeneous chemistry (red), or going on only on NAT (green) or on STS/SSA (blue).

and the $\mathrm{ClO}-\mathrm{BrO}$ catalytic cycles. No noticeable ozone production is taking place. Most of the chlorine activation is accomplished by the reaction of $\mathrm{HCl}$ with $\mathrm{HOCl}$ (both on NAT and STS/SSA), which is a result consistent with Grooß et al. (2011). There is a short time window (between 14 and 15 September) when the reaction of $\mathrm{HCl}$ with $\mathrm{ClONO}_{2}$ on STS/SSA is also contributing. Before that period, the $\mathrm{ClONO}_{2}$ concentration is rather low, as reported in Fig. 6d, because most of the nitrogen is in NAT particles. After that period, the temperature is higher, and thus the rate of the temperature-dependent reaction of $\mathrm{ClONO}_{2}$ with $\mathrm{HCl}$ on liquid aerosol is smaller. In the model run, during the first days, both NAT and liquid aerosol particles contribute to chlorine activation. After the sedimentation prevents further NAT particle existence, the reactions on liquid particles obviously prevail.

To further explore the relative role of NAT and STS/SSA, the model was run by separately switching on the heterogeneous reactions on NAT or on STS/SSA alone.

Figure 8 shows the $\mathrm{O}_{3}$ evolution with full heterogeneous chemistry (red), or with heterogeneous chemistry only on NAT (green) or on STS/SSA (blue). Although the heterogeneous reactions on NAT particles contributed to the chlorine activation during the first days (as shown in Fig. 6a), in our study, STS/SSA particles might have been effective on their own to produce the observed depletion that occurred in 10 days after 10 September. Although a single case study does not allow one to express any general statement for ozone depletion in the whole winter, our conclusion is in line with the results by Drdla and Müller (2012) (Arctic and Antarctic) and Wegner et al. (2012) and Wohltmann et al. (2013) (Arctic), who argue that cold liquid aerosols alone could provide most of the chlorine activation. A major role of STS particles in driving the extreme ozone reduction in the Arctic 2011 was found by Arnone et al. (2012).
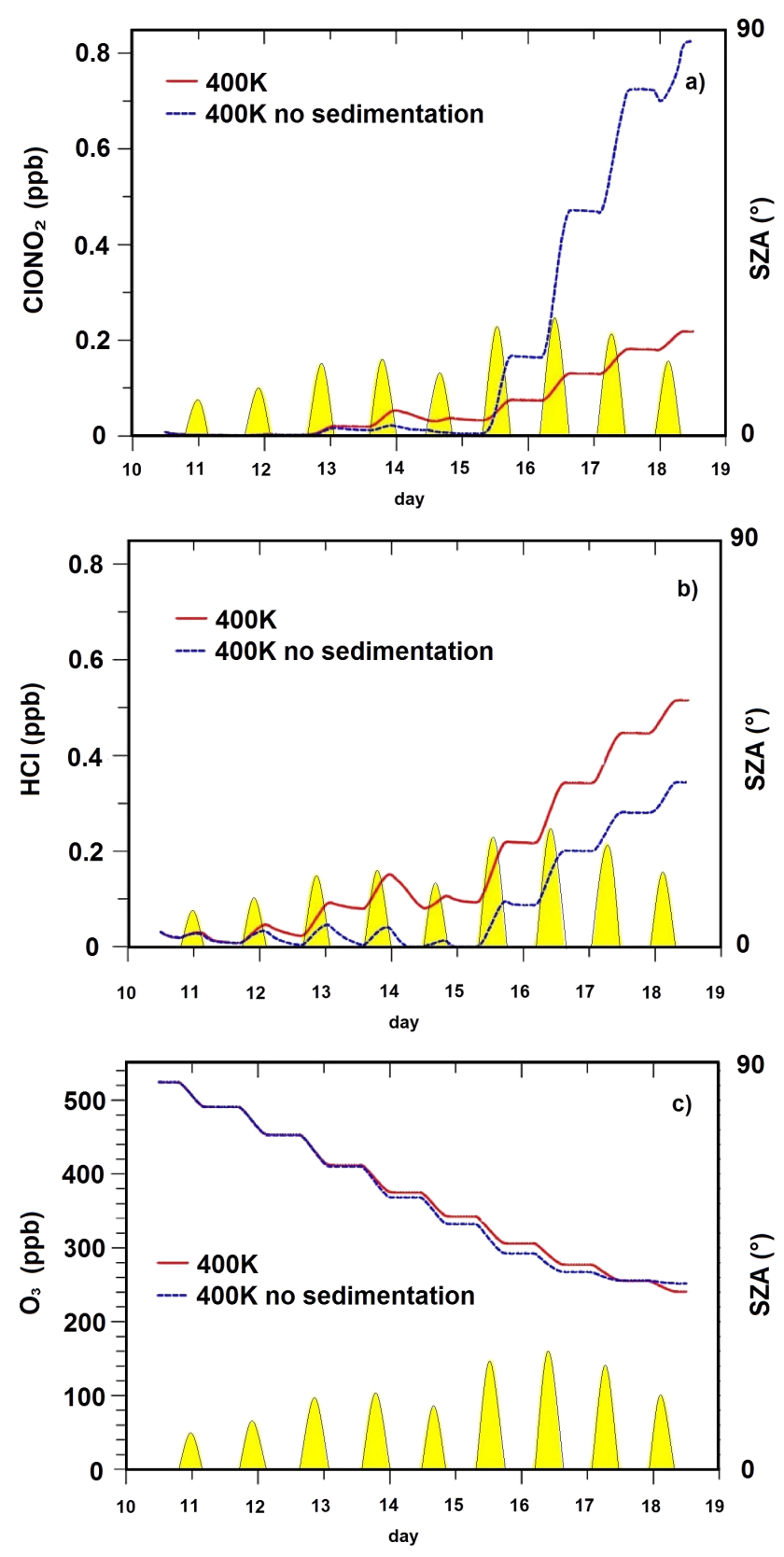

Figure 9. $\mathrm{ClONO}_{2}$ (upper panel), $\mathrm{HCl}$ (middle) and $\mathrm{O}_{3}$ (lower) evolution with (red line) and without (blue line) denitrification due to particle sedimentation.

\subsubsection{Effects of particle sedimentation}

As the influence of PSC on chemistry is twofold, providing the surface for heterogeneous reactions and removing nitrogen compounds by sedimentation (denitrification), an additional chemistry model run was performed to obtain an estimation of the effect of the denitrification on the chemistry. This was done by providing new microphysics constraints, obtained by performing a new run of the microphysical 
model that did not account for particle sedimentation. In such a configuration, a PSC was produced between 365 and $410 \mathrm{~K}$, remaining in this vertical range for 5 days, before subsequent warming caused its evaporation.

Results of this model run are depicted in Fig. 9, which reports on the time evolution of $\mathrm{ClONO}_{2}$ (Fig. 9a), $\mathrm{HCl}$ (Fig. 9b) and $\mathrm{O}_{3}$ (Fig. 9c). Red curves report simulations with sedimentation and blue curves report simulations with no sedimentation. The effect of sedimentation (denitrification) is not very large, but still detectable. In the first phase, until 16 September when temperatures were low enough for the existence of the PSC, the lack of particle sedimentation in the microphysical model allowed NAT surfaces at $400 \mathrm{~K}$ to remain high, leading to enhanced chlorine activation, and enhanced ozone loss. After 15 September, the temperature became too high for NAT existence, significantly decreasing the rates of the heterogeneous reactions on aerosols, and chlorine activation stopped. In absence of denitrification after PSC evaporation more chlorine is deactivated, the growth of $\mathrm{HCl}$ decreases by a factor 2, and similarly the buildup of $\mathrm{ClONO}_{2}$ increases by a factor 4 , as more $\mathrm{NO}_{2}$ is available so that, from the moment of PSC evaporation on, the absence of denitrification causes slightly less ozone depletion rates. The final amount of $\mathrm{HCl}$ is reduced with respect to the denitrified scenario, and that is the result of different and counteracting effects. During the PSC existence, more $\mathrm{HCl}$ is destroyed in heterogeneous reactions with $\mathrm{HOCl}$ and $\mathrm{ClONO}_{2}$, as more NAT surface is available. After the PSC evaporation, the $\mathrm{ClO}$ and $\mathrm{OH}$ mixing ratios are smaller in the not-denitrified scenario, because more $\mathrm{NO}_{2}$ and $\mathrm{HNO}_{3}$ are available to convert $\mathrm{ClO}_{x}$ and $\mathrm{HO}_{x}$ species to the reservoirs $\mathrm{ClONO}_{2}$ and $\mathrm{H}_{2} \mathrm{O}$ via the reaction of $\mathrm{ClO}$ and $\mathrm{NO}_{2}$ to produce $\mathrm{ClONO}_{2}$, and $\mathrm{OH}$ with $\mathrm{HNO}_{3}$ to produce $\mathrm{H}_{2} \mathrm{O}$ and $\mathrm{NO}_{3}$. That is why the $\mathrm{HCl}$ production by the reaction of $\mathrm{ClO}$ with $\mathrm{OH}$ is reduced. A counteracting effect results from a shift in the $\mathrm{ClO}_{x}$ partitioning: $\mathrm{Cl}$ is enhanced by the reaction of $\mathrm{ClO}$ and $\mathrm{NO}$, that produces $\mathrm{NO}_{2}$ as well, resulting in an increased $\mathrm{HCl}$ production by the reaction of $\mathrm{Cl}$ with $\mathrm{CH}_{4}$.

\section{Conclusions}

An in situ observation of an air mass when a PSC was present, by an optical particle counter and ozonometer on a balloon launched from the Antarctic station of McMurdo, where a polarization diversity lidar was also operating, provided information on PSC characteristics and ozone abundance. A trajectory analysis revealed that the air mass at around the $400 \mathrm{~K}$ level was close to McMurdo Station 10 days later, when lidar and ozone sounding were accomplished, showing a marked ozone depletion and no sign of PSC. The McMurdo in situ measurements were complemented by $\mathrm{O}_{3}, \mathrm{HCl}, \mathrm{ClONO}_{2}$ and $\mathrm{HNO}_{3}$ observations from the satellite-borne MLS and MIPAS instruments and by particle observation from the satellite-borne CALIOP li- dar, taken along the air mass trajectory connecting the two McMurdo overpass measurements. The observations have been compared to microphysical and chemical box models, run along the air mass trajectory, to investigate the evolution of the PSC and the sensitivity of the modeled chemistry to its presence. The detailed microphysical box model reproduces the evolution and type of PSC, as documented by the CALIOP observations along the air-mass trajectory. The magnitude of ozone depletion was well captured by the chemical model, as were the evolution of the reservoir species $\mathrm{HCl}$ and $\mathrm{ClONO}_{2}$. In our case study, ozone destruction processes were investigated at a time when there was already a significant amount of activated chlorine at the beginning of the simulations, and there was ozone depletion already before the time window analyzed. This probably explains why, in this case, along the trajectory investigated the effect of heterogeneous chemistry on ozone depletion was not very large, accounting for a difference of less than 8 ppbv day $^{-1}$ in the overall modeled ozone depletion rate of $35 \mathrm{ppbv}^{-1} \mathrm{y}^{-1}$, in fair agreement with an ozone loss of $\sim 30 \mathrm{ppbv} \mathrm{day}^{-1}$ that can be deduced from the balloon data. We should note that the value of the modeled ozone loss rate is within the ranges reported in the literature (Schofield et al., 2015) and the difference between its value whether heterogeneous chemistry on PSC particles has been considered, or not, is beyond both its reported atmospheric variability, and the sensitivity of our measurements. As long as a NAT PSC existed (i.e., in the first half of the time interval investigated), it contributed to the chlorine activation. However, according to our findings, under the conditions investigated, the liquid aerosols with assumed surface area densities not far from stratospheric aerosol background values, could produce the observed chlorine activation alone. Although no general conclusion can be drawn from a single case study, our findings supports the view that there may be cases when additional surface area provided by solid PSC particles does not increase appreciably the chlorine activation, since in cold conditions the activation could originate from heterogeneous chemistry on surfaces basically provided by a background aerosol distribution. As expected, differences arising from the presence of particles (whether background aerosol or PSC) and from the heterogeneous chemistry that they allow, are more remarkable when gas-phase chlorine reservoirs are examined. In fact, the buildup of $\mathrm{HCl}$ and, particularly, of $\mathrm{ClONO}_{2}$, is significantly reduced by heterogeneous reactions. Turning our attention to the effect of denitrification on ozone depletion at $400 \mathrm{~K}$, at the top of the observed PSC, we came to the conclusion that, in our study, this effect is small. In this case this may be due to two opposite effects of denitrification (and the length of the time sub-intervals in which either of these effects is dominant): (1) a reduction of the NAT surface area density and thus of their contribution to chlorine activation, and consequently of the ozone loss during the first 5 days of the simulation; (2) a counteracting reduction of chlorine deactivation and thus an 
increase in the ozone loss during the last 3 days of the simulation. Moreover, although the effects of denitrification on $\mathrm{HCl}$ and $\mathrm{ClONO}_{2}$ are opposite, so they cancel to some extent, the increase in $\mathrm{ClONO}_{2}$ (not-denitrified vs. denitrified scenario: $\sim 0.6 \mathrm{ppbv}$ by the end of the time interval) is larger than the decrease in $\mathrm{HCl}(\sim 0.2 \mathrm{ppbv})$, so that, in total, more $\mathrm{ClO}_{x}$ is converted to reservoir species in the non-denitrified case. Furthermore, the time interval that we investigate is such that, in the "with denitrification" case, the ozone depletion is still going on at the end of it, suggesting that the difference between the "with denitrification" and "without denitrification" cases might increase after the time interval we studied. In the absence of denitrification, the $\mathrm{HCl}$ concentration decreases by a factor of 2 after PSC evaporation, while the buildup of $\mathrm{ClONO}_{2}$ even quadrupled, showing how crucially the time taken for chlorine deactivation depends on $\mathrm{HNO}_{3}$ redistribution due to the gravitational settling of NAT particles.

Summarizing, state-of-the-art microphysical and chemical models are able to simulate the evolution of particles and chemicals in an air mass along a trajectory bordered by two in situ observations of particles and ozone, and remotely sensed by satellites providing additional information on key chemical species. The models are effective in explaining the observations, and investigating the relative merit of heterogeneous chemistry on NAT and STS/SSA aerosol and of denitrification on the observed ozone depletion and chlorine partitioning. Under the investigated conditions, NAT PSC presence is of little effectiveness in promoting additional ozone depletion, in comparison with what might be already occurring on background aerosols alone at low temperatures. In our case study, although the influence of denitrification was significant, but of opposite signs, on $\mathrm{ClONO}_{2}$ and $\mathrm{HCl}$ abundances, its impact on ozone depletion was small.

Acknowledgements. The authors acknowledge the Programma Nazionale di Ricerca in Antartide (PNRA) and the Progetto Congiunto di Ricerche CNR-CNRS STRACLIMA for financial support, and the National Science Foundation (NSF) for logistics and technical support on the site. J. Mercer and T. Deshler were supported by the NSF under, most recently, OPP grant 0839124. This work was also partially funded by the European Commission under grant number RECONCILE-226365-FP7-ENV-2008-1.

Edited by: F. Khosrawi

\section{References}

Achtert, P. and Tesche, M.: Assessing lidar-based classification schemes for polar stratospheric clouds based on 16 years of measurements at Esrange, Sweden, J. Geophys. Res., 119, 13861405, 2014.

Adriani, A., Deshler, T., Di Donfrancesco, G., and Gobbi, G. P.: Polar stratospheric clouds and volcanic aerosol during 1992 spring over McMurdo Station, Antarctica: Lidar and particle counter comparisons, J. Geophys. Res., 100, 25877-25898, 1995.
Adriani, A., Massoli, P., Di Donfrancesco, G., Cairo, F., Moriconi, M. L., and Snels, M.: Climatology of polar stratospheric clouds based on lidar observations from 1993 to 2001 over McMurdo Station, Antarctica, J. Geophys. Res., 109, D24211, doi:10.1029/2004JD004800, 2004.

Arnone, E., Castelli, E., Papandrea, E., Carlotti, M., and Dinelli, B. M.: Extreme ozone depletion in the 2010-2011 Arctic winter stratosphere as observed by MIPAS/ENVISAT using a 2D tomographic approach, Atmos. Chem. Phys., 12, 9149-9165, doi:10.5194/acp-12-9149-2012, 2012.

Biele, J., Tsias, A., Luo B. P., Carslaw, K. S., Neuber, R., Beyerle, G., and Peter, T.: Nonequilibrium coexistence of solid and liquid particles in Arctic stratospheric clouds, J. Geophys. Res., 106, 22991-23007, doi:10.1029/2001JD900188, 2001.

Brasseur, G. P., Tie, X. X., Rasch, P. J., and Lefèvre, F.: A threedimensional simulation of the Antarctic ozone hole: Impact of anthropogenic chlorine on the lower stratosphere and upper troposphere, J. Geophys. Res., 102, 8909-8930, 1997.

Browell, E. V., Butler, C. F., Ismail, S., Robinette, P. A., Carter, A. F., Higdon, N. S., Toon, O. B., Shoeberl, M. R., and Tuck, A. F.: Airborne lidar observations in the wintertime Arctic stratosphere: polar stratospheric clouds, Geophys. Res. Lett., 17, 385388, 1990.

Cairo, F., Di Donfrancesco, G., Adriani, A., Pulvirenti, L., and Fierli, F.: Comparison of various linear depolarization parameters measured by lidar, Appl. Optics, 38, 4425-4432, 1999.

Carlotti, M., Brizzi, G., Papandrea, E., Prevedelli, M., Ridolfi, M., Dinelli, B. M., and Magnani, L.: GMTR: Two-dimensional geofit multitarget retrieval model for Michelson Interferometer for Passive Atmospheric Sounding/Environmental Satellite observations, Appl. Optics, 45, 716-727, doi:10.1364/AO.45.000716, 2006.

Carslaw, K. S. and Peter, T.: Uncertainties in reactive uptake coefficients for solid stratospheric particles -1 . Surface chemistry, Geophys. Res. Lett., 24, 1743-1746, 1997.

Carslaw, K. S., Luo, B. P., and Peter, T.: An analytic expression for the composition of aqueous $\mathrm{HNO}_{3}-\mathrm{H}_{2} \mathrm{SO}_{4}$ stratospheric aerosols including gas phase removal of $\mathrm{HNO}_{3}$, Geophys. Res. Lett., 22, 1877-1880, 1995.

Chayka, A. M., Timofeyev, Y. M., and Polyakov, A. V.: Integral Microphysical Parameters of Stratospheric Background Aerosol for 2002-2005 (the SAGE III Satellite Experiment), Izv. Atmos. Ocean. Phys., 44, 206-220, 2008.

Dee, D. P., Uppala, S. M., Simmons, A. J., Berrisford, P., Poli, P., Kobayashi, S., Andrae, U., Balmaseda, M. A., Balsamo, G., Bauer, P., Bechtold, P., Beljaars, A. C. M., van de Berg, L., Bidlot, J., Bormann, N., Delsol, C., Dragani, R., Fuentes, M., Geer, A. J., Haimberger, L., Healy, S. B., Hersbach, H., Hólm, E. V., Isaksen, L., Kållberg, P., Köhler, M., Matricardi, M., McNally, A. P., Monge-Sanz, B. M., Morcrette, J.-J., Park, B.-K., Peubey, C., de Rosnay, P., Tavolato, C., Thépaut, J.-N., and Vitart, F.: The ERA-Interim reanalysis: configuration and performance of the data assimilation system, Q. J. Roy. Meteorol. Soc., 137, 553597, doi:10.1002/qj.828, 2011.

Deshler, T., Hervig, M. E., Hofmann, D. J., Rosen, J. M., and Liley, J. B.: Thirty years of in situ stratospheric aerosol size distribution measurements from Laramie, Wyoming $\left(41^{\circ} \mathrm{N}\right)$, using balloon-borne instruments, J. Geophys. Res., 108, 4167, doi:10.1029/2002JD002514, 2003a. 
Deshler, T., Larsen, N., Weisser, C., Schreiner, J., Mauersberger, K., Cairo, F., Adriani, A., Di Donfrancesco, G., Ovarlez, J., Ovarlez, H., Blum, U., Fricke, K. H., and Dörnbrack, A.: Large nitric acid particles at the top of an Arctic stratospheric cloud, J. Geophys. Res., 108, 4517, doi:10.1029/2003JD003479, 2003b.

Deshler, T., Mercer, J. M., Smit, H. G. J., Stubi, R., Levrat, G., Johnson, B. J., Oltmans, S. J., Kivi, R., Thompson, A. M., Witte, J., Davies, J., Schmidlin, F. J., Brothers, G., and Sasaki, T.: Atmospheric comparison of electrochemical cell ozonesondes from different manufacturers, and with different cathode solution strengths: The Balloon Experiment on Standards for Ozonesondes, J. Geophys. Res., 113, D04307, doi:10.1029/2007JD008975, 2008.

Di Liberto, L., Cairo, F., Fierli, F., DiDonfrancesco, G., Viterbini, M., Deshler, T., and Snels, M.: Observation of Polar Stratospheric clouds over Mcmurdo $(77.85 \mathrm{~S}, 166.67 \mathrm{E})$ (2006-2010), J. Geophys. Res. Atmos., 119, 5528-5541, doi:10112/2013JD019892, 2014.

Dinelli, B. M., Arnone, E., Brizzi, G., Carlotti, M., Castelli, E., Magnani, L., Papandrea, E., Prevedelli, M., and Ridolfi, M.: The MIPAS2D database of MIPAS/ENVISAT measurements retrieved with a multi-target 2-dimensional tomographic approach, Atmos. Meas. Tech., 3, 355-374, doi:10.5194/amt-3-355-2010, 2010

Douglass, A. R., Schoeberl, M. R., Stolarski, R. S., Waters, J. W., Russell, J. M., Roche, A. E., and Massie, S. T.: Interhemispheric differences in springtime production of $\mathrm{HCl}$ and $\mathrm{ClONO} 2$ in the polar vortices, J. Geophys. Res., 100, 13967-13978, 1995.

Drdla, K. and Müller, R.: Temperature thresholds for chlorine activation and ozone loss in the polar stratosphere, Ann. Geophys., 30, 1055-1073, doi:10.5194/angeo-30-1055-2012, 2012.

Dye, J. E., Baumgardner, D., Gandrud, B. W., Kawa, S. R., Kelly, K. K., Loewenstein, M., Ferry, G. V., Chan, K. R., and Gary, B. L.: Particle Size Distributions in Arctic Polar Stratospheric Clouds, Growth and Freezing of Sulfuric Acid Droplets, and Implications for Cloud Formation, J. Geophys. Res., 97, 8015-8034, doi:10.1029/91JD02740, 1992

Engel, I., Luo, B. P., Pitts, M. C., Poole, L. R., Hoyle, C. R., Grooß, J.-U., Dörnbrack, A., and Peter, T.: Heterogeneous formation of polar stratospheric clouds - Part 2: Nucleation of ice on synoptic scales, Atmos. Chem. Phys., 13, 10769-10785, doi:10.5194/acp13-10769-2013, 2013.

Engel, I., Luo, B. P., Khaykin, S. M., Wienhold, F. G., Vömel, H., Kivi, R., Hoyle, C. R., Grooß, J.-U., Pitts, M. C., and Peter, T.: Arctic stratospheric dehydration - Part 2: Microphysical modeling, Atmos. Chem. Phys., 14, 3231-3246, doi:10.5194/acp-143231-2014, 2014.

Fischer, H., Birk, M., Blom, C., Carli, B., Carlotti, M., von Clarmann, T., Delbouille, L., Dudhia, A., Ehhalt, D., Endemann, M., Flaud, J. M., Gessner, R., Kleinert, A., Koopman, R., Langen, J., López-Puertas, M., Mosner, P., Nett, H., Oelhaf, H., Perron, G., Remedios, J., Ridolfi, M., Stiller, G., and Zander, R.: MIPAS: an instrument for atmospheric and climate research, Atmos. Chem. Phys., 8, 2151-2188, doi:10.5194/acp-8-2151-2008, 2008.

Froidevaux, L., Livesey, N. J., Read, W. G., Jiang, Y. B., Jimenez, C, Filipiak, M. J., Schwartz, M. J., Santee, M. L., Pumphrey, H. C. , Jiang, J. H., Wu, D. L., Manney, G. L., Drouin, B. J., Waters, J. W., Fetzer, E. J., Bernath, P. F., Boone, C. D., Walker, K. A., Jucks, K. W., Toon, G. C., Margitan, J. J., Sen, B., Webster, C.
R., Christensen, L. E., Elkins, J. W., Atlas, E., Lueb, R. A., and Hendershot, R.: Early Validation Analyses of Atmospheric Profiles From EOS MLS on the Aura Satellite, IEEE Trans. Geosci. Remote Sensing, 44, 1106-1121, 2006.

Gobbi, G. P.: Lidar estimation of stratospheric aerosol properties: Surface, volume, and extinction to backscatter ratio, J. Geophys. Res., 100, 11219-11235, 1995.

Grooß, J. U., Pierce, R. B., Crutzen, P. J., Grose, W. L., and Russell, J. M.: Re-formation of chlorine reservoirs in southern hemisphere polar spring, J. Geophys. Res., 102, 13141-13152, 1997.

Grooß, J.-U., Brautzsch, K., Pommrich, R., Solomon, S., and Müller, R.: Stratospheric ozone chemistry in the Antarctic: what determines the lowest ozone values reached and their recovery?, Atmos. Chem. Phys., 11, 12217-12226, doi:10.5194/acp11-12217-2011, 2011.

Hitchman, M. H., McKay, M., and Trepte, C. R.: A climatology of stratospheric aerosol, J. Geophys. Res., 99, 20689-20700, 1994.

Hofmann, D. J. and Deshler, T.: Stratospheric cloud observations during formation of the Antarctic ozone hole in 1989, J. Geophys. Res., 96, 2897-2912, 1991.

Hoppel, K., Bevilacqua, R., Canty, T., Salawitch, R., and Santee, M.: A measurement/model comparison of ozone photochemical loss in the Antarctic ozone hole using Polar Ozone and Aerosol Measurement observations and the Match technique, J. Geophys. Res., 110, D19304, doi:10.1029/2004JD005651, 2005.

Hoyle, C. R., Engel, I., Luo, B. P., Pitts, M. C., Poole, L. R., Grooß, J.-U., and Peter, T.: Heterogeneous formation of polar stratospheric clouds - Part 1: Nucleation of nitric acid trihydrate (NAT), Atmos. Chem. Phys., 13, 9577-9595, doi:10.5194/acp13-9577-2013, 2013.

Komhyr, W. D.: Electrochemical concentration cells for gas analysis, Ann. Geophys., 25, 203-210, 1969.

Konopka, P., Steinhorst, H. M., Grooß, J. U., Günther, G., Müller, R., Elkins, J. W., Jost, H. J., Richard, E., Schmidt, U., Toon, G., and McKenna, D. S.: Mixing and ozone loss in the 1999-2000 Arctic vortex: Simulations with the three-dimensional Chemical Lagrangian Model of the Stratosphere (CLaMS), J. Geophys. Res., 109, D02315, doi:10.1029/2003JD003792, 2004.

Koop, T., Luo, B. P., Tsias, A., and Peter, T.: Water activity as the determinant for homogeneous ice nucleation in aqueous solutions, Nature, 406, 611-614, doi:10.1038/35020537, 2000.

Kröger, C., Hervig, M., Nardi, B., Oolman, L., Deshler, T., Wood, S., and Nichol, S.: Stratospheric ozone reaches new minima above McMurdo Station, Antarctica, between 1998 and 2001, J. Geophys. Res., 108, 4555-4567, doi:10.1029/2002JD002904, 2003.

Lambert, A., Santee, M. L., Wu, D. L., and Chae, J. H.: A-train CALIOP and MLS observations of early winter Antarctic polar stratospheric clouds and nitric acid in 2008, Atmos. Chem. Phys., 12, 2899-2931, doi:10.5194/acp-12-2899-2012, 2012.

Lowe, D. and MacKenzie, A. R.: Polar stratospheric cloud microphysics and chemistry, J. Atmos. Sol.-Terr. Phys., 70, 13-40, 2008.

Luo, B. P., Voigt, C., Fueglistaler, S., and Peter, T.: Extreme NAT supersaturations in mountain wave ice PSCs: A clue to NAT formation, J. Geophys. Res., 108, 4441, doi:10.1029/2002JD003104, 2003.

Maturilli, M., Neuber, R., Massoli, P., Cairo, F., Adriani, A., Moriconi, M. L., and Di Donfrancesco, G.: Differences in Arctic and 
Antarctic PSC occurrence as observed by lidar in Ny-Ålesund $\left(79^{\circ} \mathrm{N}, 12^{\circ} \mathrm{E}\right)$ and McMurdo $\left(78^{\circ} \mathrm{S}, 167^{\circ} \mathrm{E}\right)$, Atmos. Chem. Phys., 5, 2081-2090, doi:10.5194/acp-5-2081-2005, 2005.

McKenna, D. S., Grooß, J.-U., Günther, G., Konopka, P., Müller, R., Carver, G., and Sasano, Y.: A new Chemical Lagrangian Model of the Stratosphere (CLaMS): 2. Formulation of chemistry scheme and initialization, J. Geophys. Res., 107, 4256, doi:10.1029/2000JD000113, 2002a.

McKenna, D. S., Konopka, P., Grooß, J.-U., Günther, G., Müller, R., Spang, R., Offerman, D., and Orsolini, Y.: A new Chemical Lagrangian Model of the Stratosphere (ClaMS): 1. Formulation of advection and mixing, J. Geophys. Res., 107, 4309, doi:10.1029/2000JD000114, 2002b.

Mercer, J. L., Kröger, C., Nardi, B., Johnson, B. J., Chipperfield, M. P., Wood, S. W., Nichol, S. E., Santee, M. L., and Deshler, T.: Comparison of measured and modeled ozone above McMurdo Station, Antarctica, 1989-2003, during austral winter/spring, J. Geophys. Res., 112, D19307, doi:10.1029/2006JD007982, 2007.

Mishchenko, M. I., Travis, L. D., and Mackowski, D. W.: T-Matrix Computations of Light Scattering by Nonspherical Particles: A Review, J. Quant. Spectrosc. Radiat. T., 111, 1704-1744, doi:10.1016/0022-4073(96)00002-7, 2010.

Molleker, S., Borrmann, S., Schlager, H., Luo, B., Frey, W., Klingebiel, M., Weigel, R., Ebert, M., Mitev, V., Matthey, R., Woiwode, W., Oelhaf, H., Dörnbrack, A., Stratmann, G., Grooß, J.U., Günther, G., Vogel, B., Müller, R., Krämer, M., Meyer, J., and Cairo, F.: Microphysical properties of synoptic-scale polar stratospheric clouds: in situ measurements of unexpectedly large $\mathrm{HNO}_{3}$-containing particles in the Arctic vortex, Atmos. Chem. Phys., 14, 10785-10801, doi:10.5194/acp-14-10785-2014, 2014.

Pitts, M. C., Thomason, L. W., Poole, L. R., and Winker, D. M.: Characterization of Polar Stratospheric Clouds with spaceborne lidar: CALIPSO and the 2006 Antarctic season, Atmos. Chem. Phys., 7, 5207-5228, doi:10.5194/acp-7-5207-2007, 2007.

Pitts, M. C., Poole, L. R., and Thomason, L. W.: CALIPSO polar stratospheric cloud observations: second-generation detection algorithm and composition discrimination, Atmos. Chem. Phys., 9, 7577-7589, doi:10.5194/acp-9-7577-2009, 2009.

Pitts, M. C., Poole, L. R., Dörnbrack, A., and Thomason, L. W.: The 2009-2010 Arctic polar stratospheric cloud season: a CALIPSO perspective, Atmos. Chem. Phys., 11, 2161-2177, doi:10.5194/acp-11-2161-2011, 2011.

Plöger, F., Konopka, P., Günther, G., Grooß, J.-U., and Müller, R.: Impact of the vertical velocity scheme on modeling transport in the tropical tropopause layer, J. Geophys. Res., 115, D03301, doi:10.1029/2009JD012023, 2010.

Raspollini, P., Carli, B., Carlotti, M., Ceccherini, S., Dehn, A., Dinelli, B. M., Dudhia, A., Flaud, J.-M., López-Puertas, M., Niro, F., Remedios, J. J., Ridolfi, M., Sembhi, H., Sgheri, L., and von Clarmann, T.: Ten years of MIPAS measurements with ESA Level 2 processor V6 - Part 1: Retrieval algorithm and diagnostics of the products, Atmos. Meas. Tech., 6, 2419-2439, doi:10.5194/amt-6-2419-2013, 2013.

Riviere, E. D.: A Lagrangian method to study stratospheric nitric acid variations in the polar regions as measured by the Improved Limb Atmospheric Spectrometer, J. Geophys. Res., 108, D23, doi:10.1029/2003JD003718, 2003.
Russell, P. B., Swissler, T. J., and McCormick, M. P.: Methodology for error analysis and simulation of lidar aerosol measurements, Appl. Optics, 18, 3783-3797, 1979.

Sander, S. P. S., Friedl, R. R., Barker, J. R., Golden, D. M., Kurylo, M. J., Wine, P. H., Abbatt, J. P. D., Burkholder, J. B., Kolb, C. E., Moortgat, G. K., Huie, R. E., and Orkin, V. L.: Chemical Kinetics and Photochemical Data for Use in Atmospheric Studies, Evaluation Number 17, JPL Publication 10-06, Jet Propulsion Laboratory, Pasadena, California, 2011.

Santee, M. L., Tabazadeh, A., Manney, G. L., Fromm, M. D., Bevilacqua, R. M., Waters, J. W., and Jensen, E. J.: A Lagrangian approach to studying Arctic polar stratospheric clouds using UARS MLS HNO3 and POAM II aerosol extinction measurements, J. Geophys. Res., 107, ACH 4-1-ACH 4-13, doi:10.1029/2000JD000227, 2002.

Santee, M. L., Lambert, A., Read, W. G., Livesey, N. J., Cofield, R. E., Cuddy, D. T., Daffer W. H., Drouin, B. J., Froidevaux, L., Fuller, R. A., Jarnot, R. F., Knosp, B. W., Manney, G. L., Perun, V. S., Snyder, W. V., Stek, P. C., Thurstans, R. P., Wagner, P. A., Waters, J. W., Muscari, G., de Zafra, R. L., Dibb, J. E., Fahey, D. W., Popp, P. J., Marcy, T. P., Jucks, K. W., Toon, G. C., Stachnik, R. A., Bernath, P. F., Boone, C. D., Walker, K. A., Urban, J., and Murtagh, D.: Validation of the Aura Microwave Limb Sounder $\mathrm{HNO}_{3}$ Measurements, J. Geophys. Res., 112, D24S40, doi:10.1029/2007JD008721, 2007.

Sasano, Y., Terao, Y., Tanaka, H. L., Yasunari, T., Kanzawa, H., Nakajima, H., Yokota, T., Nakane, H., Hayashida, S., and Saitoh, N.: ILAS observations of chemical ozone loss in the Arctic vortex during early spring 1997, Geophys. Res. Lett., 27, 213-216, 2000.

Schofield, R., Avallone, L. M., Kalnajs, L. E., Hertzog, A., Wohltmann, I., and Rex, M.: First quasi-Lagrangian in situ measurements of Antarctic Polar springtime ozone: observed ozone loss rates from the Concordiasi long-duration balloon campaign, Atmos. Chem. Phys., 15, 2463-2472, doi:10.5194/acp-15-24632015, 2015.

Snels, M., Cairo, F., Colao, F., and Di Donfrancesco, G.: Calibration method for depolarization lidar measurements, Int. J. Remote Sens., 30, 5725-5736, doi:10.1080/01431160902729572, 2009.

Solomon, S.: Stratospheric ozone depletion: A review of concepts and history, Rev. Geophys., 37, 275-316, 1999.

Solomon, S., Garcia, R. R., Rowland, F. S., and Wuebbles, D. J.: On the depletion of Antarctic ozone, Nature, 321, 755-758, 1986.

Steinbrecht, W., Claude, H., Schönenborn, F., Leiterer, U., Dier, H., and Lanzinger, E.: Pressure and Temperature Differences between Vaisala RS80 and RS92 Radiosonde-Systems, J. Atmos. Ocean. Tech., 25, 909-927, doi:10.1175/2007JTECHA999.1, 2008.

Stephens, G. L., Vane, D. G., Boain, R. J., Mace, G. G., Sassen, K., Wang, Z., Illingworth, A. J., O’Connor, E. J., Rossow, W. B., Durden, S. L., Miller, S. D., Austin, R. T., Benedetti, A., Mitrescu, C., and CloudSat Science Team: The CloudSat mission and the A-Train: A new dimension of space-based observations of clouds and precipitation, B. Am. Meteorol. Soc., 83, 1771-1790, doi:10.1175/BAMS-83-12-1771, 2002.

Terao, Y., Sasano, Y., Nakajima, H., Tanaka, H. L., and Yasunari, T.: Stratospheric ozone loss in the 1996/1997 Arctic winter: Evaluation based on multiple trajectory analysis for double- 
sounded air parcels by ILAS, J. Geophys. Res., 107, 8210, doi:10.1029/2001JD000615, 2002.

Toon, O. B., Browell, E. V., Kinne, S., and Jordan, J.: An analysis of lidar observations of polar stratospheric clouds, Geophys. Res. Lett., 17, 393-396, 1990.

Tsias, A., Wirth, M., Carslaw, K. S., Biele, J., Mehrtens, H., Reichardt, J., Wedekind, C., Weiß, V., Renger, W., Neuber, R., von Zahn, U., Stein, B., Santacesaria, V., Stefanutti, L., Fierli, F., Bacmeister, J., and Peter, T.: Aircraft lidar observations of an enhanced type Ia polar stratospheric clouds during APEPOLECAT, J. Geophys. Res., 104, 23961-23969, 1999.

Voigt, C., Schreinier, J., Kohlmann, A., Zink, P., Mauersberger, K., Larsen, N., Deshler, T., Kröger, C., Rosen, J., Adriani, A., Cairo, F., Di Donfrancesco, G., Viterbini, M., Ovarlez, J., Ovarlez, H., David, C., and Dörnbrack, A.: Nitric Acid Trihydrate (NAT) in Polar Stratospheric Clouds, Science, 290, 1756-1758, 2000.

von Hobe, M., Bekki, S., Borrmann, S., Cairo, F., D’Amato, F., Di Donfrancesco, G., Dörnbrack, A., Ebersoldt, A., Ebert, M., Emde, C., Engel, I., Ern, M., Frey, W., Genco, S., Griessbach, S., Grooß, J.-U., Gulde, T., Günther, G., Hösen, E., Hoffmann, L., Homonnai, V., Hoyle, C. R., Isaksen, I. S. A., Jackson, D. R., Jánosi, I. M., Jones, R. L., Kandler, K., Kalicinsky, C., Keil, A., Khaykin, S. M., Khosrawi, F., Kivi, R., Kuttippurath, J., Laube, J. C., Lefèvre, F., Lehmann, R., Ludmann, S., Luo, B. P., Marchand, M., Meyer, J., Mitev, V., Molleker, S., Müller, R., Oelhaf, H., Olschewski, F., Orsolini, Y., Peter, T., Pfeilsticker, K., Piesch, C., Pitts, M. C., Poole, L. R., Pope, F. D., Ravegnani, F., Rex, M., Riese, M., Röckmann, T., Rognerud, B., Roiger, A., Rolf, C., Santee, M. L., Scheibe, M., Schiller, C., Schlager, H., Siciliani de Cumis, M., Sitnikov, N., Søvde, O. A., Spang, R., Spelten, N., Stordal, F., Sumin'ska-Ebersoldt, O., Ulanovski, A., Ungermann, J., Viciani, S., Volk, C. M., vom Scheidt, M., von der Gathen, P., Walker, K., Wegner, T., Weigel, R., Weinbruch, S., Wetzel, G., Wienhold, F. G., Wohltmann, I., Woiwode, W., Young, I. A. K., Yushkov, V., Zobrist, B., and Stroh, F.: Reconciliation of essential process parameters for an enhanced predictability of Arctic stratospheric ozone loss and its climate interactions (RECONCILE): activities and results, Atmos. Chem. Phys., 13, 92339268, doi:10.5194/acp-13-9233-2013, 2013.
Waters, J. W., Froidevaux, L., Harwood, R. S., Jarnot, R. F., Pickett, H. M., Read, W. G., Siegel, P. H., Cofield, R. E., Filipiak, M. J., Flower, D. A., Holden, J. R., Lau, G. K., Livesey, N. J., Manney, G. L., Pumphrey, H. C., Santee, M. L., Wu, D. L., Cuddy, D. T., Lay, R. R. , Loo, M. S., Perun, V. S., Schwartz, M. J., Stek, P. C., Thurstans, R. P., Boyles, M. A., Chandra, K. M., Chavez, M. C., Chen, G.-S., Chudasama, B. V., Dodge, R., Fuller, R. A., Girard, M. A., Jiang, J. H., Jiang, Y., Knosp, B. W., LaBelle, R. C., Lam, J. C., Lee, K. A., Miller, D., Oswald, J. E., Patel, N. C., Pukala, D. M., Quintero, O., Scaff, D. M., Van Snyder, W., Tope, M. C., Wagner, P. A., and Walch, M. J.: The Earth Observing System Microwave Limb Sounder (EOS MLS) on the Aura Satellite, IEEE Trans. Geosci. Remote Sens., 44, 10751092, doi:10.1109/TGRS.2006.873771, 2006.

Wegner, T., Grooß, J.-U., von Hobe, M., Stroh, F., Sumin'skaEbersoldt, O., Volk, C. M., Hösen, E., Mitev, V., Shur, G., and Müller, R.: Heterogeneous chlorine activation on stratospheric aerosols and clouds in the Arctic polar vortex, Atmos. Chem. Phys., 12, 11095-11106, doi:10.5194/acp-12-11095-2012, 2012.

Wohltmann, I., Wegner, T., Müller, R., Lehmann, R., Rex, M., Manney, G. L., Santee, M. L., Bernath, P., Sumin'ska-Ebersoldt, O., Stroh, F., von Hobe, M., Volk, C. M., Hösen, E., Ravegnani, F., Ulanovsky, A., and Yushkov, V.: Uncertainties in modelling heterogeneous chemistry and Arctic ozone depletion in the winter 2009/2010, Atmos. Chem. Phys., 13, 3909-3929, doi:10.5194/acp-13-3909-2013, 2013. 